\title{
Changes in progesterone receptor mRNA content in the rabbit lung during early pregnancy and after sex steroid hormone treatment
}

\author{
I Camacho-Arroyo, S T Méndez-Cruz, C Guerra-Araiza \\ and $\mathbf{M} \mathbf{A}$ Cerbón
}

Departamento de Biología, Facultad de Química, Universidad Nacional Autónoma de México, México DF, Mexico

(Requests for offprints should be addressed to I Camacho-Arroyo, Departamento de Biología, Facultad de Química, Ciudad Universitaria, Coyoacán 04510, México DF, Mexico)

\begin{abstract}
In this work we determined progesterone receptor (PR) mRNA content in female rabbit lung during the first 5 days of pregnancy and in ovariectomized animals after subcutaneous injection of oestradiol benzoate $(25 \mu \mathrm{g} / \mathrm{kg})$ for 2 days or oestradiol benzoate $(25 \mu \mathrm{g} / \mathrm{kg})$ for 2 days plus a single dose of progesterone $(5 \mathrm{mg} / \mathrm{kg})$ on day three. On each day $(0-5)$ of pregnancy and $24 \mathrm{~h}$ after the last dose in the case of the treated animals, animals were killed and lung was excised; total RNA was extracted and processed for Northern blot analysis. The results showed three main PR mRNA transcripts $(6 \cdot 1,4 \cdot 4$ and $1 \cdot 8 \mathrm{~kb})$ in rabbit lung.
\end{abstract}

The $4.4 \mathrm{~kb}$ species was the most abundant. PR mRNA content was markedly increased by oestradiol benzoate and downregulated by progesterone. It significantly increased on the first day of pregnancy and then diminished progressively, reaching its lowest value on day 5 . These findings suggest that PR mRNA content in the rabbit lung is regulated by sex steroid hormones and changes according to the physiological concentrations of oestradiol and progesterone.

Journal of Endocrinology (1998) 157, 71-74

\section{Introduction}

Progesterone participates in the regulation of respiratory function in mammals. This sex steroid hormone mediates the increase in ventilation and the reduction in alveolar carbon dioxide tension observed in the luteal phase of the menstrual cycle and during pregnancy in humans (Goodland \& Pommerenke 1952, Goodland et al. 1954). Administration of progesterone to several species including humans induces hyperventilation (Hosenpud et al. 1983, Regensteiner et al. 1989, Tatsumi et al. 1991).

Most actions of progesterone are mediated by specific intracellular progesterone receptors (PRs), which in various tissues are upregulated by oestradiol and downregulated by progesterone (Kraus \& Katzenellenbogen 1993, Camacho-Arroyo et al. 1996). It has been shown that progestins can stimulate ventilation in the female rat only when uterine $\mathrm{PR}$ concentrations are increased by previous administration of oestradiol (Brodeur et al. 1986).

PRs have been located by immunohistochemistry in several lung cell types such as alveolar epithelial cells, interstitial, endothelial and muscle cells (Camacho-Arroyo et al. 1994). It was found that oestradiol treatment of ovariectomized rabbits increased the number of PR-immunoreactive cells in the lung compared with that in ovariectomized animals treated with vehicle (CamachoArroyo et al. 1994). In the present study, we have evaluated the role of oestradiol and progesterone in the regulation of PR mRNA content in rabbit lung and its variations during early pregnancy.

\section{Materials and Methods}

Animals and treatments

Adult female New Zealand White rabbits (3-4 kg) maintained under a 12:12 h light/darkness cycle with food and water available ad libitum were used in this study. Twelve animals were ovariectomized under ketamine (Rhóne Mérieux, Querétaro, México) anaesthesia $(80 \mathrm{mg} / \mathrm{kg}$ ). Two weeks later they were randomly assigned to the following s.c. treatments (four animals/treatment): (a) daily administration of oestradiol benzoate (OB) $(25 \mu \mathrm{g} /$ $\mathrm{kg}$ ) for 2 consecutive days, (b) the above described administration of OB followed by progesterone $(5 \mathrm{mg} / \mathrm{kg})$ on day 3 , and (c) vehicle alone (corn oil). At $24 \mathrm{~h}$ after the last dose, the animals were deeply anaesthetized with ketamine, and the lung and uterus were dissected out onto ice and immediately processed for total RNA extraction.

In another experiment intact female rabbits were mated twice on the same day with an experienced buck. The day of mating was designated day 0 . Animals (four/group) were deeply anaesthetized with ketamine and killed 4, 24, 
$48,72,96$ and $120 \mathrm{~h}$ (days $0-5$ ) after the second coitus, the lung was removed onto ice and processed for RNA extraction.

\section{Northern blot analysis}

Total RNA was obtained from each tissue by the singlestep method based on guanidinium isothiocyanatephenol-chloroform extraction (Chomczynski \& Sacchi 1987) using Trizol reagent (Gibco-BRL, Inc, Gaithersburg, MD, USA). In all cases RNA extracted from each animal was individually analysed. RNA concentration was determined by measurement of absorbance at $260 \mathrm{~nm}$. Total RNA samples $(25 \mu \mathrm{g})$ were sizefractionated by electrophoresis on $1.1 \%$ agarose gels in the presence of $2 \cdot 2 \mathrm{M}$ formaldehyde and then transferred to GeneScreen membranes (New England Nuclear, Boston, MA, USA). Blotted RNAs were hybridized with $\left[\alpha-{ }^{32} \mathrm{P}\right] \mathrm{dCTP}$ PR cDNA probe labelled by the random primer method (Feinberg \& Vogelstein 1983). After hybridization, membranes were washed twice with $2 \times \mathrm{SSC}$ at room temperature for $15 \mathrm{~min}$, followed by $0 \cdot 1 \times \mathrm{SSC} / 0 \cdot 1 \% \operatorname{SDS}$ at $56{ }^{\circ} \mathrm{C}$ for $45 \mathrm{~min}$. The membranes were then exposed to Hyperfilm $\beta \max$ films (Amersham Co, Amersham, Bucks, UK) for $72 \mathrm{~h}$ at $-70{ }^{\circ} \mathrm{C}$. After exposure, membranes were stripped and rehybridized with $\left[\alpha-{ }^{32} \mathrm{P}\right] \mathrm{dCTP}-\mathrm{labelled}$ cyclophilin 18 PCR product probe obtained in our laboratory (Díaz-Sánchez et al. 1995). Cyclophilin 18 (Harding et al. 1986) was used as a constitutive gene expression control (Haendler et al. 1987). The intensity of the bands in the autoradiographs was quantified by densitometry using a Scan jet 3C apparatus (Hewlett-Packard, CA, USA). Data for PR mRNA content during early pregnancy were corrected using data for cyclophilin and analysed using one-way ANOVA followed by Student's $t$-test. The Epistat statistic program (Epistat Services, TX, USA) was used to calculate probability values.

\section{Results}

Northern blot analysis showed the presence of three main PR mRNA transcripts of $6 \cdot 1,4 \cdot 4$ and $1.8 \mathrm{~kb}$ in rabbit lung. The $4 \cdot 4 \mathrm{~kb}$ species was the most abundant transcript (Figs 1 and 2). The content of each PR mRNA transcript changed according to the steroid hormonal environment of the animals. Thus we observed that the treatment of ovariectomized rabbits with $\mathrm{OB}$ induced a marked increase in PR mRNA content in the lung whereas the administration of progesterone after $\mathrm{OB}$ priming reduced it (Fig. 1). These effects were more evident in the $4.4 \mathrm{~kb}$ PR mRNA transcript than in the others. Interestingly, the largest PR mRNA transcript $(6.1 \mathrm{~kb})$ was detected in the uterus but not in the lung of ovariectomized animals (Fig. 1). This PR mRNA transcript was clearly observed in the lung on day 1 of pregnancy (Fig. 2).

\section{VEP U}
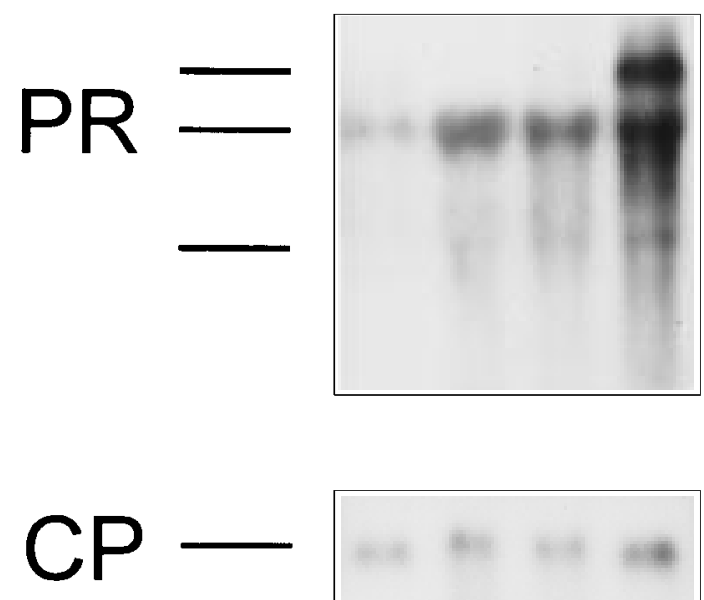

Figure $1 \mathrm{~A}$ representative Northern blot of PR mRNA from rabbit lung. Ovariectomized rabbits were treated with vehicle $(V)$, OB $(\mathrm{E})$ or $\mathrm{OB}+$ progesterone $(\mathrm{P})$ as described in Materials and Methods. Total RNA (25 $\mu \mathrm{g}$ ) was fractionated on $1 \cdot 1 \%$ agarose gels, and transferred to GeneScreen membranes which were then hybridized with both $\left[\alpha_{-}{ }^{32} \mathrm{P}\right] \mathrm{PR}$ cDNA and cyclophilin (CP) probes and exposed for $72 \mathrm{~h}$ using Hyperfilm $\beta$ max films. CP was used as a constitutive gene expression control. Lane $U$ shows PR mRNA from the uterus of ovariectomized rabbits treated with OB. The main PR mRNA transcripts $(6 \cdot 1,4 \cdot 4$ and $1 \cdot 8 \mathrm{~kb})$ are indicated.

During early pregnancy, PR mRNA content markedly changed in rabbit lung (Fig. 2). A significant increase in PR mRNA content was found on the first day of pregnancy; it then diminished progressively until it reached its lowest value on day 5 , as shown by the PR:cyclophilin ratio determined by densitometric analysis (Fig. 3).

\section{Discussion}

In this study we determined the presence of PR mRNA in rabbit lung as well as changes in its content after oestradiol and progesterone treatment and during early pregnancy. Several PR gene transcripts were found in rabbit lung, as has also been observed in the uterus of rabbit and rat (Gutiérrez-Sagal et al. 1993, Kraus \& Katzenellenbogen 1993). We observed three main PR transcripts $(6.1,4.4$ and $1.8 \mathrm{~kb})$ in the lung. The $4.4 \mathrm{~kb}$ PR mRNA species was the most abundant. The size of this transcript is similar to the main PR mRNA species reported in the chicken (Jeltsch et al. 1990), while the largest one $(6 \cdot 1 \mathrm{~kb})$ corresponds to the transcript previously described in rabbit uterus (Loosfelt et al. 1986, Misrahi et al. 1988). 


\section{5}
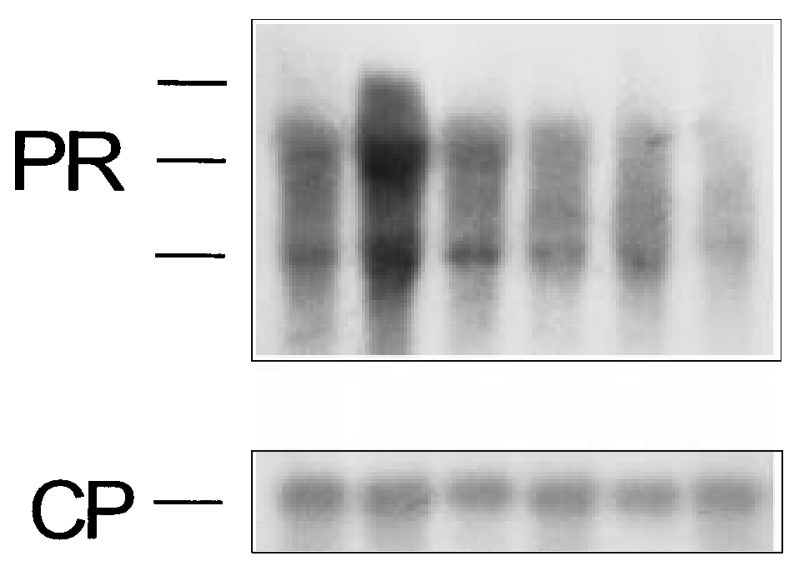

Figure 2 A representative Northern blot of PR mRNA from the lung of rabbits during early pregnancy. Total RNA ( $25 \mu \mathrm{g})$ from the lung of early pregnant rabbits (days $0-5$ ) was used for Northern blot analysis which was performed as indicated in Fig. 1. Cyclophilin (CP) was used as a constitutive gene expression control. The three main PR mRNA transcripts $(6 \cdot 1,4.4$ and $1.8 \mathrm{~kb})$ found in the lung are indicated.

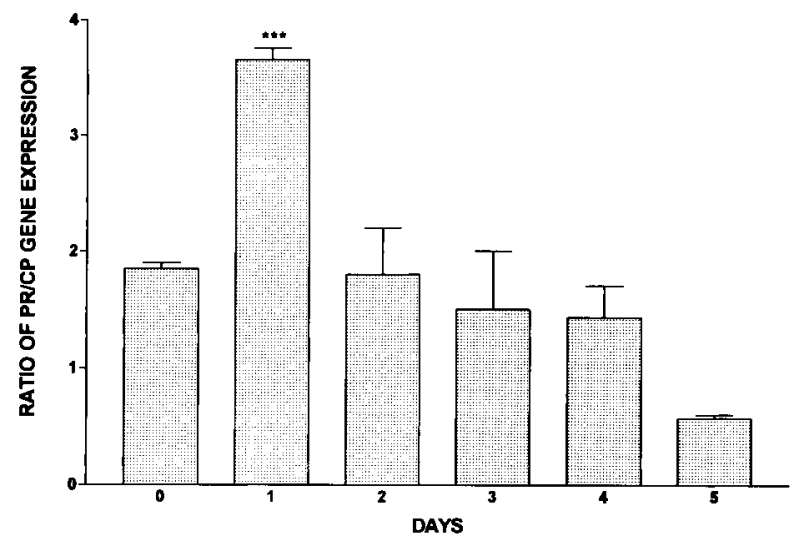

Figure 3 Densitometric analysis of PR mRNA content in the lung of early pregnant rabbits. PR mRNA content in rabbit lung during early pregnancy was corrected by using data for the constitutively expressed cyclophilin (CP) gene on days $0-5$ of pregnancy. Results are expressed as mean \pm S.E.M. from four animals. ${ }^{* * *} P<0 \cdot 05$ compared with the other days of pregnancy.

In ovariectomized rabbits, the $6 \cdot 1 \mathrm{~kb}$ PR transcript was only observed in the uterus and not in the lung (Fig. 1). However, this transcript was clearly detected in the lung of pregnant rabbits on day 1 (Fig. 2). The functional relevance of the presence of several PR transcripts in the lung is not known since, according to Loosfelt et al. (1984), only the PR B isoform is expressed in the rabbit, although the possibility of the presence of two PR isoforms in rabbit lung cannot be discounted.
We found that the relative abundance of each PR mRNA transcript in the lung changed according to the hormonal status of the animals. PR gene expression in the lung was upregulated by oestradiol and downregulated by progesterone in a manner similar to that observed in the uterus and the hypothalamus of the rabbit (CamachoArroyo et al. 1996). The effects of oestradiol and progesterone on PR gene expression may be due to changes in the rate of PR transcription or mRNA stability (Turcotte et al. 1991). PR gene expression in the lung could be up- and down-regulated by oestradiol and progesterone respectively via the oestrogen responsive element which overlaps the initiation site of transcription of the PR rabbit gene (Savouret et al. 1991).

Our results on the regulation of PR gene expression by sex steroid hormones assessed by PR mRNA content in the lung are in line with data obtained at the protein level by immunohistochemical examination (Camacho-Arroyo et al. 1994). It has been reported that oestradiol treatment of ovariectomized rabbits increased the number of PR-immunoreactive cells in the lung as compared with that of ovariectomized animals treated with vehicle alone (Camacho-Arroyo et al. 1994). There is a correlation between the effects of oestradiol on PR gene expression at both the mRNA and protein levels, suggesting that the changes in PR protein content in rabbit lung after sex steroid hormone treatment are the result of modifications at the transcriptional level.

During early pregnancy, PR mRNA was detected in rabbit lung on day 0 , with a marked increase on day 1 followed by a clear diminution on days $2-5$ (Figs 2 and 3). This PR gene expression pattern was similar to that found in rabbit endometrium, although in the latter the highest PR gene expression was found on day 2; on day 3 PR mRNA content was still high and diminished until days 4 and 5 (Gutierrez-Sagal et al. 1993). These differences are probably due to the presence of tissue-specific factors that regulate PR gene expression differently in the uterus and lung. Interestingly, in the case of the uterus, no correlation was found between PR mRNA and PR protein content: on day 3 of pregnancy endometrial PR protein was not detectable in spite of the high PR mRNA content (Gutierrez-Sagal et al. 1993). Although we observed a correlation between the effects of oestradiol on PR mRNA content and PR protein levels (Camacho-Arroyo et al. 1994) in the lung, it is necessary to determine whether this correlation is maintained during early pregnancy in order to understand other aspects of PR gene expression regulation and the physiological meaning of $\mathrm{PR}$ changes in the lung during early pregnancy.

Our results suggest that, under physiological conditions, PR mRNA content in the lung depends on the concentration of sex steroid hormones. Maximal PR mRNA content was observed on day 1 of pregnancy when plasma progesterone concentration is low, whereas the lowest PR 
mRNA content occurred on day 5 after a marked increase in plasma progesterone concentration (Challis et al. 1973, Hilliard \& Eaton 1971).

Although it has been shown that progesterone can increase the content of flavin-containing mono-oxygenase isoform B in rabbit lung (Lee et al. 1993) and decrease both $\beta$-adrenergic receptor activity and cAMP levels (Moawad et al. 1982, Nabishah et al. 1992), hitherto the molecules regulated by progesterone via PR activation, which are involved in the increase in ventilation and the reduction in alveolar carbon dioxide tension observed during pregnancy, are not known and deserve further investigation.

\section{Acknowledgements}

We thank Professor E Milgrom of Hôpital de Bicêtre, France, for the generous supply of rabbit PR cDNA. We also thank Adriana Mendoza and Juana Gonzáles for technical assistance with the experiments, and M L A Flora García-Formentí of CELE, Universidad Nacional Autónoma de México (UNAM) for revision of the English. This work was supported by Facultad de Química, UNAM, México.

\section{References}

Brodeur P, Mockus M, McCullogh R \& Moore LG 1986 Progesterone receptors and ventilatory stimulation by progestin. Journal of Applied Physiology 60 590-595.

Camacho-Arroyo I, Ruiz A, Gamboa-Domínguez A, Pérez-Palacios G \& Cerbón MA 1994 Immunohistochemical localization of intracellular progesterone and glucocorticoid receptors in the rabbit lung. Journal of Endocrinology 142 311-316.

Camacho-Arroyo I, Pasapera AM \& Cerbón MA 1996 Regulation of progesterone receptor gene expression by sex steroid hormones in the hypothalamus and the cerebral cortex of the rabbit. Neuroscience Letters 214 25-28.

Challis JRG, Davies IJ \& Ryan KJ 1973 The concentrations of progesterone, estrone and estradiol-17 $\beta$ in the plasma of pregnant rabbits. Endocrinology 93 971-976.

Chomczynski P \& Sacchi N 1987 Single-step method of RNA isolation by acid guanidinium thiocyanate-phenol-chloroform extraction. Analytical Biochemistry 162 156-159.

Díaz-Sanchez V, Morimoto S, Morales A, Robles-Díaz G \& Cerbón MA 1995 Androgen receptor in the rat pancreas: genetic expression and steroid regulation. Pancreas 11 241-245.

Feinberg A \& Vogelstein B 1983 A technique for radiolabelling DNA restriction endonuclease fragments to high specific activity. Analytical Biochemistry 137 6-13.

Goodland RL \& Pommerenke WT 1952 Cyclic fluctuations of the alveolar carbon dioxide tension during the normal menstrual cycle. Fertility and Sterility 3 394-401.

Goodland RL. Reynolds JG, McCoord AB \& Pommerenke WT 1954 Alveolar carbon dioxide tension levels during pregnancy and early puerperium. Journal of Clinical Endocrinology and Metabolism 14 $522-530$.

Gutiérrez-Sagal R, Pérez-Palacios G, Langley E, Pasapera AM, Castro I \& Cerbón MA 1993 Endometrial expression of progesterone receptor and uteroglobin genes during early pregnancy in the rabbit. Molecular Reproduction and Development 34 244-249.

Haendler B, Hoefer-Waerbinek R \& Hofer E 1987 Complementary DNA for human T-cell cyclophilin. EMBO Journal 6 947-950.

Harding MW, Handschumacher RE \& Speicher DW 1986 Isolation and amino acid sequence of cyclophilin. Journal of Biological Chemistry $2618547-8555$.

Hilliard J \& Eaton LWM 1971 Estradiol-17ß, progesterone and $20,5 \alpha$-hydroxypregn-4-en-3-one in rabbit ovarian venous plasma. II. From mating through implantation. Endocrinology 89 522-527.

Hosenpud JD, Hart MV, Morton MJ, Hohimer AR \& Resko JA 1983 Progesterone-induced hyperventilation in the guinea pig. Respiration Physiology 52 259-264.

Jeltsch JM, Turcotte B, Garnier JM, Lerouge T, Krozowski Z, Gronemeyer H \& Chambon P 1990 Characterization of multiple mRNAs originating from the chicken progesterone receptor gene. Journal of Biological Chemistry 265 3967-3974.

Kraus WL \& Katzenellenbogen BS 1993 Regulation of progesterone receptor gene expression and growth in the rat uterus: modulation of estrogen actions by progesterone and sex steroid hormone antagonists. Endocrinology 132 2371-2379.

Lee MY, Clark JE \& Williams DE 1993 Induction of flavincontaining monooxygenase (FMO B) in rabbit lung and kidney by sex steroids and glucocorticoids. Archives of Biochemistry and Biophysics 302 332-336.

Loosfelt H, Logeat F, Vu Hai MT \& Milgrom E 1984 The rabbit progesterone receptor. Evidence for a single steroid-binding subunit and characterization of receptor mRNA. Journal of Biological Chemistry 259 14196-14202.

Loosfelt H, Atger M, Misrahi M, Guiochon-Mantel A, Meriel C, Logeat F, Benarous R \& Milgrom E 1986 Cloning and sequence analysis of rabbit progesterone-receptor complementary DNA. Proceedings of the National Academy of Sciences of the USA $\mathbf{8 3}$ 9045-9049.

Misrahi M, Loosfelt H, Atger M, Mériel C, Zerah V, Dessen P \& Milgrom E 1988 Organisation of the entire rabbit progesterone receptor mRNA and of the promoter and $5^{\prime}$ flanking region of the gene. Nucleic Acids Research 16 5459-5472.

Moawad AH, River LP \& Kilpatrick SJ 1982 The effect of estrogen and progesterone on $\beta$-adrenergic receptor activity in rabbit lung tissue. American Journal of Obstetrics and Gynecology 144 608-613.

Nabishah BM, Khalid BAK, Morat PB, Alias AK \& Zainuddin M 1992 Effects of steroid hormones on cyclic adenosine $3^{\prime}, 5^{\prime}$ monophosphate levels in the rat lung. Journal of Endocrinology 134 73-76.

Regensteiner JG, Woodard WD, Hagerman DD, Weil JV, Picket CK, Bender PR \& Moore LG 1989 Combined effects of female hormones and metabolic rate on ventilatory drives in women. Journal of Applied Physiology 66 808-813.

Savouret JF, Bailly A, Misrahi M, Rauch C, Redeuilh G, Chauchereau A \& Milgrom E 1991 Characterization of the hormone responsive element involved in the regulation of the progesterone receptor gene. EMBO Journal 10 1875-1883.

Tatsumi K, Mikami M, Kuriyama T \& Fukuda Y 1991 Respiratory stimulation by female hormones in awake male rats. Journal of Applied Physiology 71 37-42.

Turcotte B, Meyer MC, Bellard M, Dretzen G, Gronemeyer H \& Chambon P 1991 Control of transcription of the chicken progesterone receptor gene. In vitro and in vivo studies. Journal of Biological Chemistry 266 2582-2589.

Received 21 April 1997

Revised manuscript received 6 October 1997 Accepted 28 October 1997 